\title{
IMPLEMENTASI LAYANAN BIMBINGAN KELOMPOK MELALUI STRATEGI KOLABORATIF (PEMANFAATAN ICT) PADA ANAK
}

\author{
Siti Fadillah ${ }^{1}$, Sean Marta Efastri ${ }^{2}$, Eva Karnelia ${ }^{3}$ \\ Fakultas Keguruan dan Ilmu Pendidikan, Universitas Lancang Kuning ${ }^{1,2}$, PAUD Pelangi Kids ${ }^{3}$ \\ Email: sitifadillah@unilak.ac.id ${ }^{1}$, Email: seanmarta@unilak.ac.id ${ }^{2}$, Email: \\ evakarnelia@gmail.com \\ Fadillah ,Siti., Sean Marta Efastri., Eva Karnelia. (2021). Implementasi Layanan Bimbingan Kelompok \\ Melalui Strategi Kolaboratif (Pemanfaatan Ict) pada Anak. Jurnal Pelita PAUD, 6(1), 155-161. \\ doi: https://doi.org/10.33222/pelitapaud.v4i1.780
}

\begin{abstract}
Abstrak: Berdasarkan fenomena menunjukan bahwa guru dalam memberikan layanan bimbingan kelompok dengan strategi kolaboratif masih tergolong belum maksimal terutama dalam memanfaatkan ICT. Peneliti tertarik untuk melakukan penelitian guna mengetahui secara detail implementasi layanan bimbingan kelompok melalui strategi kolaboratif yang dilakukan oleh guru pada anak dengan judul penelitian. Maka metode yang digunakan adalah jenis penelitian Quasi Eksperimen, penelitian ini dilakukan di PAUD Pelangi Kids Usia 5-6 Thaun. Berdasarkan hasil analisis data dan pembahasan dalam penelitian ini maka dapat ditarik kesimpulan bahwa impelementasi layanan BK melalui strategi kolaboratif pemanfaatan ICT pada anak PAUD Pelangi Kids menunjukan implementasinya berjalan baik, dimana hasil penelitian ketika sebelum dilakukan layanan BK pemahaman anak masih tergolong rendah dengan rata-rata mencapai 15.8 sedangkan hasil dari penerapan layanan BK kepada anak menambahkan pemahaman anak tergolong tinggi dengan rata-rata mencapai 23.0.
\end{abstract}

Kata kunci: Layanan Bimbingan Kelompok, Strategi Kolaboratif, Pemanfaatan ICT.

Abstract: Based on the phenomenon, it shows that teachers in providing group guidance services with collaborative strategies are still not optimal, especially in utilizing ICT. Researchers are interested in conducting research to find out in detail the implementation of group guidance services through collaborative strategies carried out by teachers on children with the title of research. So the method used is a quasi-experimental type of research. Based on the results of data analysis and discussion in this study, it can be concluded that the implementation of BK services through a collaborative strategy of using ICT in Pelangi Kids PAUD children shows that the implementation is going well, where the results of research before the BK service was carried out, children's understanding was still relatively low with an average of reaching 15.8 while the results of implementing $B K$ services to children added that children's understanding was classified as high with an average of 23.0.

Keywords: Group Guidance Services, Collaborative Strategy, ICT Utilization.

(C) 2021 Siti Fadilla, Sean Marta Efastri, Eva Karnelia Under the license CC BY-SA 4.0

http://jurnal.upmk.ac.id/index.php/pelitapaud 


\section{PENDAHULUAN}

Semua anak yang dilahirkan memiliki potensi, yaitu anak yang memiliki fisik normal maupun anak yang berkebutuhan khusus (Hamalik, 2007) . Lingkungan berperan untuk membantu mengoptimalkan pertumbuhan secara optimal namun perubahan perkembangan pada anak usia dini dapat berlangsung secara optimal dan bisa juga tidak optimal pada setiap anak karena disebabkan adanya perbedaan individu yaitu setiap anak mempunyai keunikan tersendiri. (Zulma, 2018)

Perkembangan anak usia dini merupakan sebuah proses pertumbuhan dan perkembangan yang bersifat dinamis dan berkelanjutan. Anak usia dini yaitu anak yang berusia dari 0 hingga 6 tahun yang melewati masa bayi, masa balita, dan masa prasekolah. Pada setiap masa yang dilalui oleh anak usia dini akan menunjukan perkembangan masingmasing yang berbeda antara masa bayi, balita dan pra sekolah (Ardy, 2014). Anak usia dini merupakan tahapan tumbuh kembang yang optimal yaitu masa golden age dimana anak pada fase ini yang tepat mendapatkan stimulasi dan memberikan aspek-aspek tertentu untuk berkembang secara optimal (Kemp \& Dayton, 2010).

Dalam memfasilitasi perkembagan anak maka melalui pendidikan formal, non formal maupun informal anak bisa mandiri dan percaya diri sehingga tidak bergantung kepada orang lain. Taman Kanak-kanak adalah jalur pendidikan formal untuk anak usia dini dan bertujuan untuk memberikan stimulasi sehingga anak akan lebih bertahan. Pendidikan anak usia dini diselenggarakan bagi anak sejak lahir sampai enam tahun dan bukan merupakan prasyarat untuk mengikuti pendidikan dasar (UU No 20 tahun 2003 pasal ayat 1). Mengasuh, membimbing dan memberikan pengajaran yang tepat yaitu upaya untuk menstimulasi agar anak mampuy dan memiliki keterampilan (Hildayani, 2012). Pendidikan anak usia dini dimulai dari keluyar bukan dari sekolah, sekolahan formal hanya mempersiapkan anak melanjutkan ke sekolah dasar.

Layanan Bimbingan Konseling di sekolah pada dasarnya untuk membantu mengembangkan diri, sikap dan kebiasaan belajar yang baik, menguasai kemampuan dan keterampilan serta menyiapkan diri untuk melanjutkan pendidikan pada tingkat yang lebih tinggi, dalam pelaksanaannya Bimbingan Konseling tidak lepas dari peran serta Kepala Sekolah, koordinasi antara guru pembimbingan dengan guru bidang studi, orang tua siswa, dan juga masyarakat. Pelayanan Konseling di Sekolah merupakan usaha membantu siswa dalam pengembangan dan perkembangan karir, baik secara individual maupun kelompok sesuai dengan kebutuhan, potensial, bakat, minat, serta peluang yang dimiliki (Hartinah, 2009). Seringkali seorang siswa dalam mengambil keputusan dalam menghadapi tantangan maupun hambatan dalam masalah akademi dan non akademi, berbeda antara satu dengan yang lainnya, hal ini dipengaruhi oleh pola asuh orang tua maupun lingkungan sekolah (Dimyati \& Mudjiono, 2009). Bimbingan Konseling sebagai wadah untuk pendisiplinan perilaku, memerlukan adanya perencanaan , pelaksanaan layanan khusus, evaluasi perilaku terhadap program yang sudah dilakukan. Problematika berkaitan dengan akademik siswa merupakan bagian tanggung jawab dari layanan Bimbingan dan Konseling di Sekolah. Hal ini sesuai dengan Rambu-rambu Penyelenggaraan Bimbingan dan Konseling dalam Jalur Pendidikan Formal (ABKIN, 2007) yang menyatakan bahwa pelayanan bimbingan konseling untuk semua siswa dilaksanakan dalam rangka pengembangan potensi secara optimal serta mengembangkan kemandirian dalam pengambilan keputusan. Optimalisasi pelayanan bimbingan dan konseling perlu dilakukan sehingga pelayanan bimbingan dan konseling benar-benar memberikan konstribusi pada penetapan visi, misi, dan tujuan sekolah. (Anriani et al., 2021) Asumsi dasar yang melandasi bahwa Taman Kanak-kanak memerlukan bimbingan adalah kesetaraan TK sekarang ini dengan pendidikan dasar dan menengah. Jika di lingkungan pendidikan dasar dan menengah bimbingan sangat dibutuhkan, otomatis PAUD atau TK juga membutuhkannya. Selain keahlian dan pengalaman pendidik, faktor lain yang perlu diperhatikan adalah kecintaan yang 
tulus pada anak, berminat pada perkembangan mereka, bersedia mengembangkan potensi yang dimiliki pada anak, hangat dalam bersikap dan bersedia bermain dengan anak. Maka dalam hal ini bimbingan bagi anak usia dini sangat dibutuhkan dalam perkembangan anak terutama dalam sistem layanan bimbingan yang diberikan (Wahab, 2009).

Berbagai macam layanan yang biasanya digunakan untuk bimbingan dalam ranah AUD, dari sekian banyaknya layanan hanya ada beberapa layanan yang dapat diterapkan pada AUD. Setelah mengenali berbagai macam layanan yang dapat diterapkan ada pula teknik dalam melakukan bimbingan di PAUD atau TK. Layanan bimbingan bagi anak tentunya dibutuhkan kemampuan guru dalam menggunakan metode yang tepat (Nuzliah, 2017). Guru harus membimbing murid agar mereka memperoleh keterampilan keterampilan, pemahaman, perkembangan sebagai kemampuan, kebiasaan-kebiasaan yang baik, dan perkembangan sikap yang serasi, oleh karena itu ia harus melakukan banyak hal agar pengajarannya berhasil. Maka dalam hal ini kegiatan belajar mengajar sangat membutuhkan peran seorang guru (Hamalik, 2007). Terutama dalam kegiatan pemberian layanan bimbingan kelompok.

Layanan bimbingan kelompok merupakan layanan bimbingan yang menggunakan suasana kelompok untuk memberi informasi atau mengentaskan permasalahan anak (Prayitno, 2005). Dengan layanan bimbingan kelompok para anak dapat diajak untuk bersama-sama mengemukakan pendapat tentang suatu dan memberikan topik penting, mengembangkan nilai-nilai tentang hal tersebut serta mengembangkan langkahlangkah bersama untuk menangani permasalahan yang dibahas dalam kelompok (Tohirin, 2007).

Layanan bimbingan kelompok bertujuan untuk mendorong pengembangan perasaan, pikiran, persepsi, wawasan dan sikap yang menunjang perwujudan tingkah laku yang lebih efektif, sehingga segala bentuk bimbingan akan mampu mengarahkan kepada perkembangan anak yang semakin baik dalam berprilaku ataupun melakukan suatu kegiatan (Prayitno \& Amti, 2004) .

Layanan bimbingan kelompok yang dilakukan oleh guru dapat dipadukan dengan strategi kolaboratif (Mulyasa, 2005). Strategi kolaboratif merupakan salah satu strategi dengan sistem membentuk kelompok untuk dapat bekerja sama sehingga kelompok tersebut akan dapat di bimbing dan diberikan layanan bimbingan dalam setiap permasalahan setiap anak terutama dalam kemampuan perkembangan anak (Barkely \& Dkk, 2016).

Pemberian layanan bimbingan kelompok melalui kolaborasi (pemanfaatan ICT) akan lebih memudahkan guru dalam memberikan bimbingan kelompok (Hildayani, 2012) pada setiap anak, dimana setiap anak akan dibentuk dalam satu kelompok dan berkolaborasi dengan guru dalam membahas materi yang sama dengan adanya tampilan ICT, Setelah setiap anak berkolaborasi dengan guru yang menggunakan ICT dalam pembahasan materi tentunya setiap masalah yang sedang dibahas akan mudah dipecahkan serta guru akan mudah memberikan bimbingan dan pengarahan kepada anak. Selain itu kegiatan ini tentunya akan lebih menyenangkan bagi anak (Sriyanti, 2015).

Impelementasi layanan bimbingan kelompok dengan strategi kolaboratif (pemanfaatan ICT) (Sudjiono, 2009) akan dapat memacu anak lebih mandiri dan aktif dalam melakukan setiap kegiatan belajar yang diarahkan oleh guru, sebab dengan setiap bimbingan kelompok yang diberikan saat anak melakukan kegiatan kolaborasi dengan guru serta laptop sebagai media ICTnya tentunya akan lebih menarik serta akan dapat memudahkan guru dalam membimbing setiap anak dalam kelompok (Ridwan, 2011).

Meskipun konselor sekolah memiliki tanggung jawab utama dalam mengembangkan program-program komprehensif, namun mereka tidak dapat memenuhi tantangan global ini tanpa bantuan dan dukungan dari para profesional lain, sistem sekolah, dan masyarakat (Bhakti, 2016).

Dengan demikian, maka secara sistematis para konselor sekolah harus memulai hubungan kolega dengan beragam ahli pendidikan dan 
P ISSN 2548-6284 E ISSN 2615-0360

Vol. 6 No. 1 Desember 2021

medis yang menyediakan layanan tambahan bagi populasi atau peserta didik di sekolah (Hidayat, 2013). Dalam Permendikbud 111 Tahun 2014, dijelaskan bahwa kolaborasi adalah kegiatan fundamental layanan BK dimana konselor atau guru bimbingan dan konseling bekerja sama dengan berbagai pihak atas dasar prinsip kesetaraan, saling pengertian, saling menghargai dan saling mendukung. Semua upaya kolaborasi diarahkan pada suatu kepentingan bersama, yaitu bagaimana agar setiap peserta didik/konseli mencapai perkembangan yang optimal dalam aspek perkembangan pribadi, sosial, belajar dan karirnya.

Kolaborasi dilakukan antara konselor atau guru bimbingan dan konseling dengan guru mata pelajaran, wali kelas, orang tua, atau pihak lain yang relevan untuk membangun pemahaman dan atau upaya bersama dalam membantu memecahkan masalah dan mengembangkan potensi peserta didik/ konseli. (Nugraha \& Rahman, 2017)

Berdasarkan hasil pengamatan di PAUD Pelangi Kids Rumbai menunjukan secara ratarata selama ini layanan bimbingan kelompok dengan strategi kolaboratif sudah dijalankan atau digunakan oleh para guru dalam pembelajaran, namun masih juga terlihat impelementasi layanan bimbingan kelompok melalui strategi kolaboratif belum maksimal dilakukan oleh para guru dan terlihat fenomena yakni: 1) Masih adanya sebagian anak yang belum paham pada topik pembahasan ketika setelah diajarkan layanan bimbingan kelompok, hal ini terlihat kurangnya kemampuan guru memberikan layanan bimbingan kelompok dengan mamanfaatkan ICT saat menggunakan strategi kolaboratif seperti laptop, selama ini hanya menggunakan kegiatan kelompok saja berupa tugas dan kegiatan saat melakukan bimbingan kelompok, 2) masih adanya guru merasa kesulitan dalam menerapkan layanan bimbingan kelompok dengan strategi kolaboratif dengan memanfaatkan ICT, 3) masih ada guru yang kesulitan menyesuaikan materi yang digunakan untuk layanan bimbingan kelompok dengan strategi kolaboratif melaui media ICT.

Menurut Mc Croskey (dalam Litle John dan Foss, 2009: 113) upaya yang dapat dilakukan untuk mengurangi kecemasan dalam berkomunikasi yaitu dengan melakukan training individual (Budiningsih, 2004). Bimbingan kelompok merupakan salah satu layanan bimbingan dan konseling yang melatihkan keterampilan berkomunikasi kepada siswa dan membantu siswa mengatasi permasalahan-permasalahan dalam berkomunikasi (Aswida et al., 2012).

Tujuan dari bimbingan kelompok menurut (Prayitno, 2005) antara lain : (1) Mampu berbicara di depan banyak orang. (2) Mampu mengeluarkan pendapat, ide, saran, tanggapan, perasaan dan lain sebagainya kepada orang banyak. (3) Belajar menghargai pendapat orang lain. (4) Bertanggung jawab atas pendapat yang dikemukakannya. (5) Mampu mengendalikan diri dan menahan emosi (gejolak kejiwaan yang bersifat negatif). (6) Dapat bertenggang rasa. (7) Menjadi akrab satu sama lainnya. (8) Membahas masalah atau topik-topik umum yang dirasakan atau menjadi kepentingan bersama.

Berdasarkan pendapat di atas dapat disimpulkan bahwa kegiatan bimbingan kelompok dapat membantu mengatasi permasalahan siswa dalam berkomunikasi, seperti kecemasan berkomunikasi.

Peningkatan moral dan disiplin anak usia dini yang diterapkan dengan bimbingan kelompok melalui metode permainan sangat membantu anak untuk mengetahui dan memahami hal apa saja yang berkaitan dengan moral dan disiplin (Winkel, 2006). Sehingga mereka mampu menerapkan sikap moral dan disiplin dengan baikdalam kehidupan sehari-hari. Hal ini juga sangat didukung oleh beberapa media yang digunakan seperti permainan-permainan yang edukatif, terarah, dan menciptakan suasana yang menyenangkan (Islami, 2017).

Berdasarkan fenomena di atas menunjukan bahwa guru dalam memberikan layanan bimbingan kelompok dengan strategi kolaboratif masih tergolong belum maksimal terutama dalam memanfaatkan ICT (Barkely \& Dkk, 2016). Dari latar belakang tersebut peneliti tertarik untuk melakukan penelitian guna mengetahui secara detail implementasi layanan bimbingan kelompok melalui strategi kolaboratif yang dilakukan oleh guru pada anak dengan judul penelitian "Impelementasi Layanan Bimbingan Kelompok Melalui 
P ISSN 2548-6284 E ISSN 2615-0360

Vol. 6 No. 1 Desember 2021

Strategi Kolaboratif (Pemanfaatan ICT) Pada Anak Usia 5-6"

\section{METODE PENELITIAN}

Metode yang digunakan adalah jenis penelitian Quasi Eksperimen (Sugiyono, 2014). Penelitian ini dilaksanakan pada bulan Juli 2020 dengan tempat yang dijadikan lokasi penelitian yakni di PAUD Pelangi Kids Rumbai. Populasi penelitian ini adalah anak PAUD Pelangi Kids Rumbai usia 5-6 tahun terdiri dari 8 anak. (Sugiyono, 2010)

\section{HASIL DAN PEMBAHASAN}

Pretest Pemahaman Anak tentang Topik Hidup Sehat dengan Tidak terkena Virus Covid 19 di PAUD Pelangi Kids Rumbai

Berdasarkan hasil perhitungan statistik deskriptif pemahaman anak tentang topic hidup sehat dengan tidak terkena virus covid 19 sebelum impelemnetasi layanan BK melalui strategi kolaboratif (pemanfaatan ICT) di PAUD Pelangi Kids, teridentifikasi ada tiga kategori yaitu tinggi, sedang, rendah. pemahaman anak tentang topic hidup sehat dengan tidak terkena virus covid 19 pada anak usia 5-6 tahun berdasarkan tinggi, sedang, rendah dapat dilihat pada tabel 1 . berikut ini:

Tabel 1. Statistik deskriptif kategori Pretest pemahaman anak tentang topic hidup sehat dengan tidak terkena virus covid 19 atau sebelum impelementasi layanan BK melalui strategi kolaboratif.

\begin{tabular}{ccccccc}
\hline No & Kategori & \multicolumn{3}{c}{ Skor } & f & Persentase(\%) \\
\hline 1 & Tinggi & 24 & - & 32 & 0 & 0.0 \\
\hline 2 & Sedang & 17 & - & 23 & 4 & 50.0 \\
\hline 3 & Rendah & 8 & - & 16 & 4 & 50.0 \\
\hline & Jumlah & & & & $\mathbf{8}$ & $\mathbf{1 0 0}$ \\
\hline
\end{tabular}

Berdasarkan tabel diatas diketahui bahwa pemahaman anak tentang topic hidup sehat dengan tidak terkena virus covid 19 pada anak usia 5-6 tahun sebelum impelemnetasi layanan BK melalui strategi kolaboratif (pemanfaatan ICT) di PAUD Pelangi Kids, anak yang berkategori tinggi tidak ada, yang berkategori Sedang sebanyak 4 anak $(50 \%)$ dan yang berkategori rendah sebanyak 4 anak (50\%). Perbandingan jumlah anak yang memiliki pemahaman anak tentang topic
Implementasi Layanan Bimbingan .... Siti Fadilla' ${ }^{1}$ Sean Marta Efastri2 Eva Karnelia ${ }^{3}$

hidup sehat dengan tidak terkena virus covid 19 tinggi.

Postest Pemahaman Anak tentang Topik Hidup Sehat dengan Tidak terkena Virus Covid 19 di PAUD Pelangi Kids Rumbai

Langkah selanjutnya peneliti memberikan treatment dengan layanan BK pada anak usia 5-6 tahun. Setelah dilakukan treatment peneliti melakukan posttest sehingga diperoleh hasil sebagai berikut :

Diketahui bahwa Pemahaman Anak tentang Topik. Hidup Sehat dengan Tidak terkena Virus Covid 19 usia 5-6 Tahun setelah menerapkan layanan BK, anak yang berkategori tinggi sebanyak 6 anak (75\%), yang berkategori Sedang sebanyak 2 anak $(25 \%)$ dan yang berkategori rendah tidak ada. Perbandingan jumlah anak yang memiliki kemampuan mengenal huruf tinggi, sedang dan rendah dapat divisualisasikan pada grafik

Berdasarkan kategorisasi skor k Pemahaman Anak tentang Topik Hidup Sehat dengan Tidak terkena Virus Covid 19 usia 5-6 Tahun maka dapat disimpulkan bahwa Pemahaman Anak tentang Topik Hidup Sehat dengan Tidak terkena Virus Covid 19 setelah menerapkan layanan BK berada pada tingkat tinggi. Artinya Pemahaman Anak tentang Topik Hidup Sehat dengan Tidak terkena Virus Covid 19 seperti anak dapat menjawab pertanyaan setelah dijelaskan pembelajaran hal ini dikarenakan adanya layanan BK dengan strategi kolaboratif ICT di PAUD Pelangi Kids.

Berdasarkan pemaparan diatas dapat diketahui bahwa sebagian besar anak yang mengalami peningkatan Pemahaman Anak tentang Topik Hidup Sehat dengan Tidak terkena Virus Covid 19 tidak ada yang berkategori tinggi, kemudian mengalami peningkatan menjadi 6 anak atau semua anak dengan persentase atau $75 \%$ setelah diberikan perlakuan dengan layanan BK dengan strategi kolaboratif. Sedangkan yang berada pada kategori sedang yang pada awalnya sebanyak 4 anak atau $50 \%$ kemudian pada kategori sedang setelah diberikan perlakuan tidak ada atau $25 \%$. Selanjutnya yang berada pada kategori rendah yang pada awalnya sebanyak 7 anak atau 58\% 
PISSN 2548-6284 E ISSN 2615-0360

Vol. 6 No. 1 Desember 2021

kemudian mengalami peningkatan yaitu tidak terdapat anak dengan kategori rendah.

Kolaborasi adalah suatu teknik pengajaran dengan melibatkan sejawat untuk saling mengoreksi. Kolaborasi adalah ajang bertegur sapa dan bersilaturahmi ilmu pengetahuan. Selain itu ada pembelajaran bersama (social learning) (Alwasilah, 2007). Salah satu prinsipnya adalah bahwa setiap orang memiliki kelebihan tersendiri. (Nugraha \& Rahman, 2017). Dalam kolaborasi setiap orang dibiarkan mengembangkan potensi dan kesenangannya masing-masing. Komitmen dan niat masing-masing individu menetukan pula keberhasilan mereka dalam menjalankan tugas. (Islami \& Gustiana, 2020). Berdasarkan hasil penelitian impelemnetasi layanan BK melalui strategi kolaboratif pada anak usia 5-6 tahun di PAUD Pelangi Kids, sebelum eksperimen terlebih dahulu melaksanakan pretest berupa pengisian lembar observasi terhadap pemahaman anak. Dari hasil pretest diperoleh jumlah nilai sebesar 126 dengan rata-rata 15.75 . Setelah melaksanakan eksperimen dengan layanan BK dengan strategi kolaboratif ICT, maka tahap selanjutnya melaksanakan posttest berupa pengisian lembar observasi terhadap pemahaman anak tentang hidup sehat wabah covid 19 pada anak usia 5-6 tahun. Dari hasil posttest diperoleh jumlah nilai sebesar 184 dan rata-rata 23.0

Pengujian dengan menggunakan t-test berkorelasi uji dua pihak. Untuk membuat keputusan apakah perbedaan itu signifikan atau tidak, maka harga $t$ hitung tersebut perlu dibandingkan dengan harga $t$ tabel dengan $\mathrm{dk}$ $\mathrm{n}-1=8-1=7$.

Berdasarkan tabel dalam nilai distribusi t, bila df 11 , untuk uji satu pihak dengan taraf kesalahan 5\%, maka harga t tabel $=2.365$. Bila t hitung jatuh pada daerah penerimaan Ha, maka Ha yang menyatakan pemahaman pada anak usia 5-6 tahun sesudah perlakuan lebih tinggi dari sebelum perlakuan diterima. Berdasarkan perhitungan, ternyata harga $t$ hitung 9.989 jatuh pada penerimaan $\mathrm{Ha}$ atau penolakan Ho. Besarnya kontribusi impelemnetasi layanan BK melalui strategi kolaboratif pada anak usia 5-6 tahun di PAUD Pelangi Kids sebesar $46 \%$ berada pada kategori sedang.
Adanya peningkatan terjadi, hal ini karena menurut Sukardi (Sukardi, 2008) "Layanan bimbingan kelompok adalah layanan yang memungkinkan sejumlah peserta didik secara bersama-sama memperoleh bahan dari nara sumber tertentu (terutama guru pembimbing atau konselor) yang berguna untuk menunjang kehidupan sehari-hari baik individu sebagai pelajar anggota keluarga, dan masyarakat serta untuk mempertimbangkan dalam pengambilan keputusan (Aqib, 2009).

Hasil dari penelitian dan teori tersebut menujukan adanya pengaruh yang positif terhadap pemahaman anak setelah dilakukan dengan layanan BK melalui strategi kolaboratof ICT, hal ini telah di buktikan ketika pemahaman anak sebelum dilakukan dengan layanan BK melalui strategi kolaboratif masih tergolong rendah, sedangkan setelah dilakukan dengan layanan BK melalui strategi kolaboratif ICT anak secara langsung mengamati beberapa video dan gambar cara mencegah virus covid 19 sehingga hidup dengan sehat memberikan peningkatan pemahaman menjadi lebih tinggi.

\section{SIMPULAN}

Berdasarkan hasil analisis data dan pembahasan dalam penelitian ini maka dapat ditarik kesimpulan bahwa impelementasi layanan BK melalui strategi kolaboratif pemanfaatan ICT pada anak PAUD Pelangi Kids menunjukan implementasinya berjalan baik, dimana hasil penelitian ketika sebelum dilakukan layanan BK pemahaman anak masih tergolong rendah dengan rata-rata mencapai 15.8 sedangkan hasil dari penerapan layanan BK kepada anak menambahkan pemahaman anak tergolong tinggi dengan rata-rata mencapai 23.0. hal ini juga dibuktikan perbedaan antara sebelum dan sesudah perlakuan yakni t hitung $=9.989$

$>\mathrm{t}$ tabel $=2.365$. selain itu kontribusi yang diberikan dari implemnetasi layanan BK kepada anak yakni sebesar $46 \%$ tergolong sedang. Artinnya implementasi layanan BK melalui strategi kolaboratif ICT sudah dilakukan baik dan berdampak terhadap pemahaman anak yang semakin baik di PAUD Pelangi Kids Rumbai. 
PISSN 2548-6284 E ISSN 2615-0360

Vol. 6 No. 1 Desember 2021

\section{DAFTAR PUSTAKA}

Anriani, S. R., Hasanuddin, \& Alam, A. S. P. (2021). Strategi Kolaboratif dalam Manajemen Pelayanan Bimbingan dan Konseling di Sekolah. JUBIKOPS: Jurnal Bimbingan Konseling Dan Psikologi, 1(1), 48-62.

Aqib, Z. (2009). Penelitian Tindakan Kelas untuk Guru SD, SLB, TK. (Yrama Widy).

Ardy, N. W. (2014). Buku Ajar Penanganan Anak Usia Dini Berkebutuhan Khusus (Bumi Aksar).

Aswida, W., Marjohan, \& Syukur, Y. (2012). Efektifitas Layanan Bimbingan Kelompok dalam Mengurangi Kecemasan Berkomunikasi pada Siswa. KONSELOR Jurnal Ilmiah Konseling, 1(1), 1-11.

Barkely, E., \& Dkk. (2016). Collaborative Learning Techniques. Nusa Media.

Budiningsih, A. (2004). Pembelajaran Moral. Rineka Cipta.

Dimyati, \& Mudjiono. (2009). Belajar dan Pembelajaran. Rineka Cipta.

Hamalik, O. (2007). Proses Belajar Mengajar. Bumi Aksara.

Hartinah, S. (2009). Konsep Dasar Bimbingan Kelompok. Revika Aditama.

Hildayani, R. (2012). Penanganan Anak dengan Kebutuhan Khusus. Universitas Terbuka.

Islami, C. C. (2017). Layanan Bimbingan Kelompok untuk Mengembangkan Moral dan Disiplin Anak dengan Metode Permainan. Jurnal Pelita Paud, 1(2).

Islami, C. C., \& Gustiana, E. (2020). Layanan Bimbingan dan Konseling AUD Berbasis Tugas Perkembangan untuk Meningkatkan Perilaku Prososial. Jambura Early Childhood Education Journal, 2(2), 70-78.

Kemp, J., \& Dayton. (2010). Kemp, Jhons Planing and Producing Instructional Media. Cambridge Harper \& Row Publisher.

Mulyasa. (2005). Menjadi Guru Profesional Menciptakan Pembelajaran Kreatif dan Menyenangkan. Rosda.

Nugraha, A., \& Rahman, F. A. (2017). Strategi Kolaborasi Orangtua dengan Konselor dalam
Implementasi Layanan Bimbingan .... Siti Fadilla' Sean Marta Efastri2 Eva Karnelia ${ }^{3}$

Mengembangkan Sukses Studi Siswa. Jurnal Konseling GUSJIGANG, 3(1).

Nuzliah. (2017). Pendekatan Layanan BK pada Anak Usia Dini. Jurnal.

Prayitno. (2005). PrayitnoBimbingan dan Konseling Kelompok (Dasar dan Profil). Bumi Aksara.

Prayitno, \& Amti, E. (2004). Dasar-dasar Bimbingan dan Konseling. Bumi Aksara.

Ridwan. (2011). Belajar Mudah Penelitian. Alfabeta.

Sriyanti, L. (2015). Model Bimbingan dan Konseling Kolaboratif untuk Meningkatkan Pengendalian Diri Anak Usia Dini PAUD Kota Salatiga tahun 2015. Jurnal.

Sudjiono, A. (2009). Pengantar Statistik Pendidikan. Raja Grafindo Persada.

Sugiyono. (2010). Metode Penelitian Administrasi. Alfabeta.

Sugiyono. (2014). Metode Penelitian Kuantitatif, Kualitatif dan $R \& D$. CV Alfabeta.

Sukardi, D. K. (2008). Pelaksanaan Bimbingan Konseling di Sekolah. Rineka Cipta.

Tohirin. (2007). Bimbingan dan Konseling di Sekolah dan Madrasah (Berbasis Integrasi). Grafindo Persada.

Wahab, A. A. (2009). Metode dan Model Model Mengajar. Alfabeta.

Winkel, W. (2006). Bimbingan dan Konseling di Institusi Pendidikan. Gramedia.

Zulma, A. (2018). Implementasi Bentuk Layanan Bimbingan dan Konseling pada Anak Kelompok B1 Usia 5-6 Tahun TK Islam Terpadu Permata Mandiri Billah 3 Banyuwangi Tahun Ajaran 2017/2018. Jurnal. 